\title{
Evidence for trophic differences between live and bycatch oceanic juvenile loggerhead sea turtles
}

\author{
Cheila Raposo ${ }^{1} \cdot$ Ana Rita Patrício ${ }^{2,3}\left[\right.$ [ $\cdot$ Paulo Catry ${ }^{2} \cdot$ Thomas Dellinger $^{4,5} \cdot$ José P. Granadeiro $^{1}$
}

Received: 20 July 2018 / Accepted: 7 January 2019 / Published online: 31 January 2019

c) Springer-Verlag GmbH Germany, part of Springer Nature 2019

\begin{abstract}
The loggerhead sea turtle Caretta caretta is a vulnerable migratory species that spends its first years of life in the open sea. During this developmental phase, loggerheads can be found foraging in the epipelagic zone of the waters surrounding the Madeira Archipelago, providing a rare opportunity to gather information on the ecology of its oceanic developmental stage. In this study, we characterized the isotopic niche of these juveniles, using stable isotope analysis. We assessed two groups of turtles, turtles captured alive $(n=24)$ and turtles captured as bycatch on local longlines $(n=12)$, and explored whether animals caught in the local fishing gear represented a random sample of the population, or whether there is some evidence for a specialized foraging behaviour. We found that turtle bycatch had a significantly higher mean stable nitrogen isotope value in whole blood $\left(\delta^{15} \mathrm{~N}=8.5 \pm 0.6 \%\right.$ o SD) compared to the group of turtles captured alive in the same period $\left(\delta^{15} \mathrm{~N}=7.6 \pm 0.5 \%\right.$ o $\mathrm{SD}$ ), indicating that they had a different diet. While there was a tendency for turtle bycatch to be slightly larger, we found no effect of body size on $\delta^{15} \mathrm{~N}$ values. We propose a distinct foraging behaviour strategy hypothesis, with a group of turtles being more susceptible to interactions with fisheries and thus having a higher mortality risk, which should motivate the implementation of existing guidelines to reduce sea turtle bycatch.
\end{abstract}

Responsible Editor: L. Avens.

Reviewed by D. Freggi and E. Seney.

Ana Rita Patrício

R.Patricio@exeter.ac.uk

1 Centre for Environmental and Marine Studies, Departamento de Biologia Animal, Faculdade de Ciências da Universidade de Lisboa, 1749-016 Lisbon, Portugal

2 MARE, Marine and Environmental Sciences Centre, ISPA, Instituto Universitário, 1149-041 Lisbon, Portugal

3 Centre for Ecology and Conservation, College of Life and Environmental Sciences, University of Exeter, Cornwall Campus, Penryn TR10 9EZ, UK

4 CIBIO, Research Centre in Biodiversity and Genetic Resources, InBIO Associate Laboratory, 4485-661 Vairão, Portugal

5 Laboratório de Biologia Marinha e Oceanografia, Universidade da Madeira, 9000-107 Funchal-Madeira, Portugal

\section{Introduction}

The loggerhead sea turtle Caretta caretta spends its first years of life in pelagic habitats of the open sea. This developmental stage, dubbed 'the lost years' as the whereabouts of the turtles is typically uncertain, corresponds to the main growth phase for the juveniles, lasting from 6 to 12 years (Bjorndal et al. 2000, 2003; Avens and Snover 2013). After this period, they usually leave the open ocean as they approach the subadult stage, and recruit to neritic waters (McClellan and Read 2007). Varying with their ontogenetic phase and associated trophic niche, the loggerheads are exposed to different threats, such as fisheries bycatch, plastic ingestion, marine pollution, nesting habitat destruction, and illegal harvesting, among others (Dellinger 2008), with fisheries bycatch identified as the main cause of mortality for this species (Lucchetti and Sala 2010).

Large numbers of pelagic juvenile loggerheads are encountered in the eastern Atlantic, particularly in the oceanic region of the Madeira Archipelago, Portugal, where important fisheries also occur, and interactions have been reported (Encarnação 1998). Genetic studies (Bolten et al. 1998), satellite tracking data (McCarthy et al. 2010; Mansfield et al. 2014; Freitas et al. 2018) and tag returns 
(Dellinger 2008) have shown that these juveniles originate primarily from nesting populations in the western Atlantic. Throughout this developmental stage, juveniles are known to be opportunistic predators, feeding on a variety of pelagic organisms (Parker et al. 2003; Jones and Seminoff 2013). A study in the waters around Madeira found that, after plastics and other debris, the item with major occurrence on the digestive tract contents of 35 dead juvenile loggerhead turtles was gelatinous material (Moreira 2006). Similarly, in the Azores, cnidarians were the main dietary component in the stomach of 12 dead specimens, and to a lesser extent, siphonophores, nudibranchs, pelagic gastropods, marine insect egg masses and oceanic crabs (Frick et al. 2009). In another study with live turtles captured in the waters around the Madeira and Azores Archipelagos, macroscopic observations of the gut contents of five juvenile loggerheads revealed a large presence of epipelagic salps and gastropods, while microscopic observations exposed a large number of cnidarian nematocysts (van Nierop and den Hartog 1984).

Although stomach content analysis is the most direct method to assess the feeding ecology, it only provides a snapshot of the diet, and it is a highly invasive method. The latter is irrelevant if only dead animals are analysed, but at the cost of limiting sample size and potentially biasing results, if stranded turtles have different foraging habits. Stable isotope analysis (SIA) is an alternative approach to infer the feeding ecology and trophic structure, particularly in species difficult to observe in their natural habitat, such as sea turtles. It only requires a small tissue sample (e.g. skin, blood, carapace scutes), thus processing is much faster and less invasive, and depending on the isotopic tissue turnover, it gives a longer lasting picture of an animal's diet. The isotopic turnover corresponds to the time that it takes for a consumer's tissue to reflect the isotopic composition of its diet (Hall et al. 2015), and it is variable among tissue types. Blood, for instance, due to its high metabolic rates compared to carapace or skin, has a rapid turnover rate, thus reflecting recently consumed food resources (Reich et al. 2008). The stable isotopes of nitrogen $\left(\delta^{15} \mathrm{~N}\right)$ and carbon $\left(\delta^{13} \mathrm{C}\right)$ are useful in the marine ecosystems to estimate trophic position and foraging habitat (oceanic vs. neritic or pelagic vs. benthic), respectively (Hall et al. 2015). The $\delta^{15} \mathrm{~N}$ of a consumer is typically enriched by $3-4 \%$ relative to its diet (Hatase et al. 2002); thus, there is a progressive enrichment of $\delta^{15} \mathrm{~N}$ per trophic level in food webs. The $\delta^{13} \mathrm{C}$ is only enriched by $1 \%$ o relative to its diet (Hatase et al. 2002); however, there are four gradients that can affect the $\delta^{13} \mathrm{C}$ values in marine ecosystems: nearshore/offshore, benthic/pelagic, enriched/ depleted $\delta^{13} \mathrm{C}$ food webs and low/high latitudes (Ceriani et al. 2012).

The oceanic region of the Madeira Archipelago has an ideal geographic position to investigate the foraging ecology of pelagic juvenile loggerheads, lying in their main area of distribution in the North Atlantic. Given that during their pelagic stage in the waters of Madeira these juveniles are particularly susceptible to bycatch in the depth-drifting longlines, we assess here two groups of turtles: turtles captured alive by researchers and dead turtles obtained as fishery bycatch. We here present the first report of the trophic niche of juvenile pelagic loggerheads in the region, using SIA, and investigate if animals caught in the depth-drifting longlines represent a random sample of the general population, or whether they display a different foraging behaviour that makes them more susceptible to capture and is reflected in their isotope profile.

\section{Materials and methods}

\section{Study site}

Marine turtles were captured within the Exclusive Economic Zone (EEZ) of the Madeira Archipelago, in deep water south of Madeira Island. The Madeira Archipelago, Portugal, is located off the northwest coast of Africa $\left(33^{\circ} \mathrm{N}, 17^{\circ} \mathrm{W}\right)$ and is included in the general North Atlantic circulation system with the Canary current as the dominant surface current and the NE trades the dominant wind regimes (Fig. 1).

\section{Turtle captures and measurements}

Captures were conducted between July and October 2016. Twenty-four individuals were captured alive ('live turtles') during active searches by boat, by approaching them at slow speed from behind and scooping them up with a large dipnet. After capture, turtles were transported to land-based holding facilities where they were measured and sampled, the whole process lasting under $30 \mathrm{~min}$, after which they were kept moist in the shade, and safely released near their capture location. Twelve specimens caught in the depthdrifting longlines for black scabbardfish (Aphanopus carbo), which is operated at depths ranging from 600 to $700 \mathrm{~m}$, were obtained through collaboration with local fishers ('turtle bycatch'). Turtle bycatch was kept frozen until further analysis. Each individual turtle was measured according to standard biometry procedures (Bolten 1999).

\section{Sample collection and preparation}

For the group of turtles captured alive, blood samples (up to $4 \mathrm{~mL}$ ) were collected from the dorsal post-occipital sinus. Necropsies of turtle bycatch were performed according to Wolke and George (1981), and blood samples were collected from the body cavity. As turtle bycatch was frozen shortly after being captured, we were able to collect fresh blood. All blood samples were collected using sterile single-use 


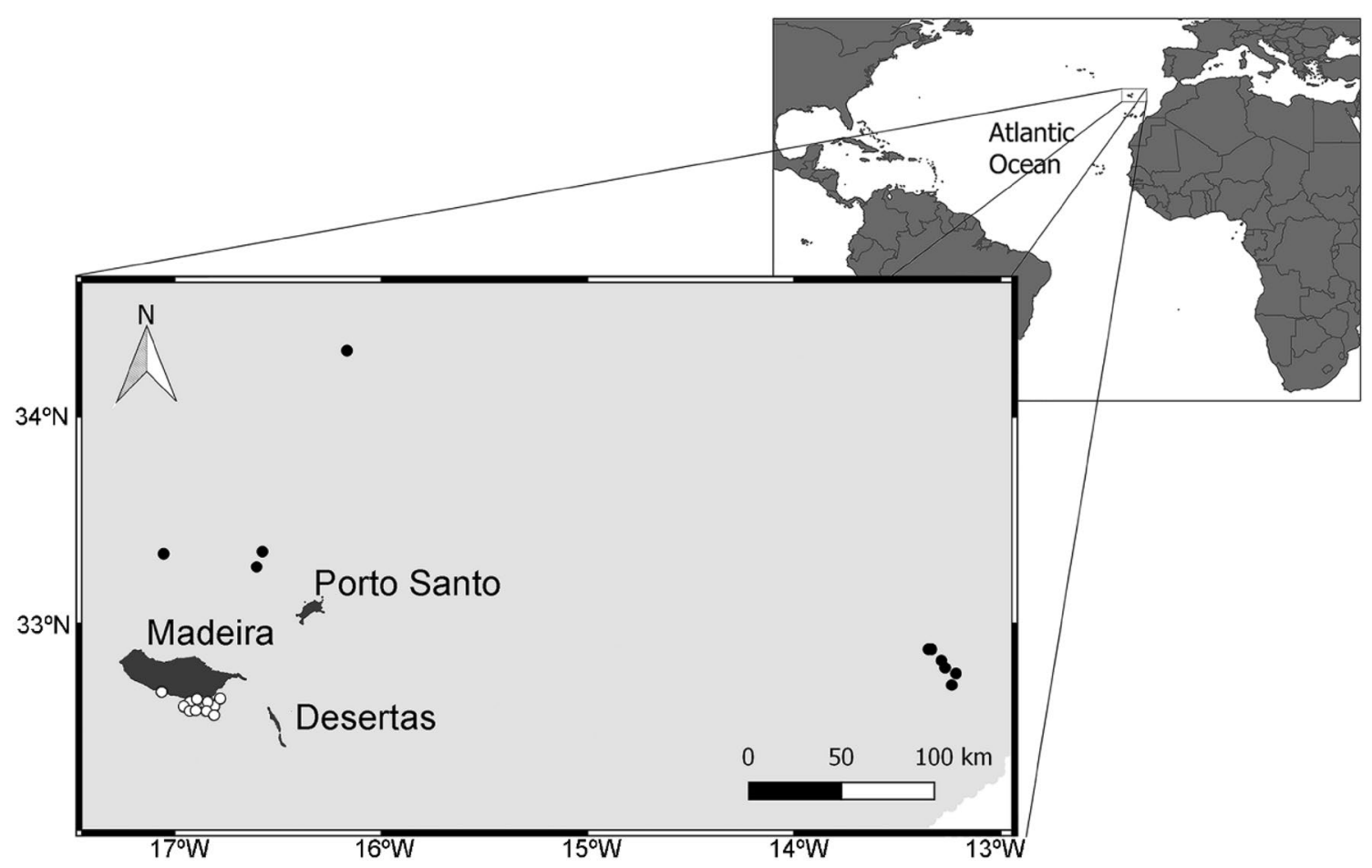

Fig. 1 Map of the northeast Atlantic showing the Madeira Archipelago and the capture sites of loggerhead sea turtles Caretta caretta captured as bycatch in depth-drifting longlines (black dots) and tur-

syringes, dried at $60{ }^{\circ} \mathrm{C}$ for $24 \mathrm{~h}$ and then frozen at $-80{ }^{\circ} \mathrm{C}$ (Seminoff et al. 2006). Blood was chosen due to its rapid turnover rate (27.7 \pm 3.5 days, Reich et al. 2008) as we were interested in the recent diet of juvenile loggerheads, i.e. the food sources foraged around Madeira. Samples of neon flying squid (Ommastrephes bartramii), the bait used in the depth-drifting longlines for black scabbardfish, were also collected during the necropsies (from the oesophagus and in the stomach), and directly from local fishermen. These samples were freeze-dried for $48 \mathrm{~h}$ and stored at $-80^{\circ} \mathrm{C}$.

\section{Stable isotope analysis}

Stable isotope analyses were conducted by continuous flow isotope mass spectrometry (CF-IRMS) on a Sercon Hydra 20-22 (Sercon, UK) stable isotope ratio mass spectrometer, coupled to a EuroEA (EuroVector, Italy) elemental analyser for online sample preparation by Dumas combustion, in the Stable Isotopes and Instrumental Analysis Facility in the University of Lisbon. The standards used were Protein Standard OAS, Sorghum Flour Standard OAS (Elemental Microanalysis, UK) and IAEA-N1 (IAEA, Vienna, Austria). Carbon $\left(\delta^{13} \mathrm{C}\right)$ and nitrogen $\left(\delta^{15} \mathrm{~N}\right)$ ratios were expressed as the relative difference $(\% o)$ between the sample and conventional standards (Pee Dee Belemnite carbonate and N2 in air, respectively) according to tles captured alive for this study (open circles), within the Economic Exclusive Zone of the Madeira Archipelago, Portugal

$\delta X=\left[\frac{R_{\text {sample }}}{R_{\text {standard }}}-1\right] \times 1000(\% \circ o)$,

where $X=\delta^{13} \mathrm{C}$ or $\delta^{15} \mathrm{~N}$ and $R={ }^{13} \mathrm{C} /{ }^{12} \mathrm{C}$ or ${ }^{15} \mathrm{~N} /{ }^{14} \mathrm{~N}$ (Seminoff et al. 2006). Precision of the isotope ratio analysis, calculated using values from six to nine replicates of laboratory standard material interspersed among samples in every batch analysis, was $\leq 0.1 \%$.

\section{Statistical analysis}

We visually inspected the biometric (SCLn-t, straight carapace length notch to tip) and the isotopic $\left(\delta^{13} \mathrm{C}\right.$ and $\left.\delta^{15} \mathrm{~N}\right)$ data with histograms and QQ plots, and analysed skewness to assess normality. Thus, the difference in biometric measurements between turtles captured alive and turtles incidentally captured, and the difference in isotopic signatures between the two groups and between the neon flying squid and the live turtles and turtle bycatch were evaluated using an ANOVA. We then applied a generalized linear model (GLM) with Gaussian error structure and identity function to assess the relationship between the isotopic signature of nitrogen (indicative of trophic level) and three potential explanatory variables: body size (SCLn-t), condition (alive or bycatch), and $\delta^{13} \mathrm{C}$. Analyses were performed using $\mathrm{R}$ 
v.3.2.5 (Development Core Team 2008). Estimates are presented as mean \pm standard deviation $(\mathrm{SD})$.

\section{Results}

\section{Size structure of Caretta caretta}

A summary of the biometric data is presented in Table 1 . The SCLn-t was used as an indicator of body size, as this is the most common measurement used in sea turtle studies, allowing comparisons. Turtle bycatch showed a size range from 264 to $493 \mathrm{~mm}$ with an average of $381 \pm 62 \mathrm{~mm}$ while the group of turtles captured alive showed a size range from 195 to $571 \mathrm{~mm}$ with an average of $332 \pm 111 \mathrm{~mm}$. All turtles analysed were oceanic juveniles (Fig. 2). An one-way ANOVA indicated that there was no significant difference in mean body size between the two groups: $F(1,34)=1.98$, $P=0.169$, although there was a tendency for turtle bycatch to be slightly larger.

\section{Trophic level of Caretta caretta}

The nitrogen isotopic signatures obtained in the blood were significantly different between the live turtles and turtle bycatch (one-way ANOVA, $F(1,34)=24.3, P<0.001$, Fig. 3), with a significantly higher mean value of $\delta^{15} \mathrm{~N}$ recorded for the bycatch $(8.5 \pm 0.6 \%$ ) compared to the live turtles $(7.6 \pm 0.5 \% o)$. In contrast, there was no significant difference on $\delta^{13} \mathrm{C}$ among live turtles $(-18.7 \pm 0.6 \%$ ) and turtle bycatch $(-18.8 \pm 0.4 \%$ ) (one-way ANOVA, $F(1$, $34)=0.60, P<0.446)$. The GLM provided a good fit for our dataset explaining $45 \%$ of the deviance. There were

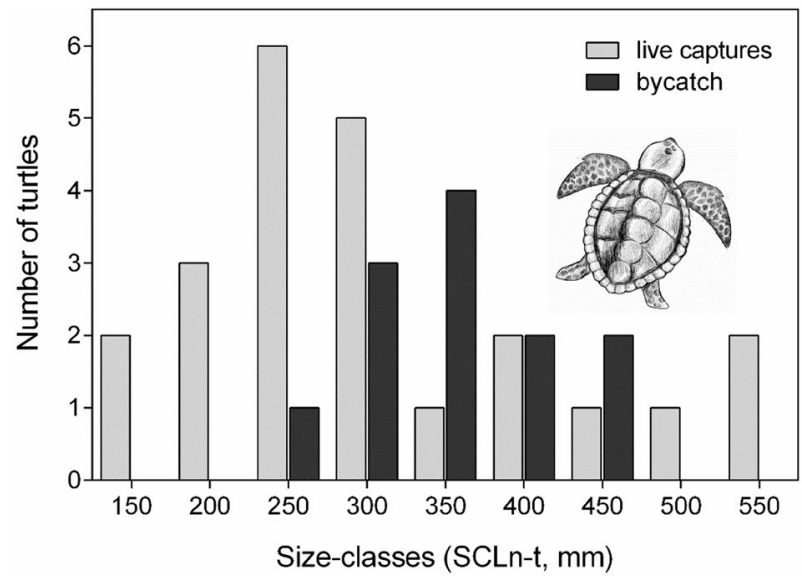

Fig. 2 Size distribution of loggerhead sea turtles Caretta caretta captured alive ( $n=23$, light grey) and incidentally captured and killed in depth-drifting longlines ( $n=12$, black) at the waters surrounding the Madeira Archipelago, Portugal. SCLn-t straight carapace length notch to tip

no significant correlations between $\delta^{15} \mathrm{~N}$ values and either body size $(F(1,34)=2.75, P=0.107$, Fig. 4$)$ or $\delta^{13} \mathrm{C}(F(1$, $34)=0.60, P=0.459)$, and the only predictor that was significantly correlated with $\delta^{15} \mathrm{~N}$ was condition (alive vs. bycatch: $\left.F(1,34)=24.3, P^{<} 0.0001\right)$. The mean values of $\delta^{15} \mathrm{~N}$ and $\delta^{13} \mathrm{C}$ for the neon flying squids were $10.8 \pm 0.8 \%$ o and $-19.9 \pm 0.4 \%$, respectively (Fig. 3 ). The nitrogen isotopic signature of the neon flying squids was significantly different from that of both live turtles (one-way ANOVA, $F(1,29)=178.4, P<0.001$, Fig. 3 ) and turtle bycatch (oneway ANOVA, $F(1,17)=49.9, P<0.001$, Fig. 3$)$. The carbon isotopic signature obtained of the neon flying squid was also significantly distinct from those of live turtles
Table 1 Biometrical data collected from juvenile loggerhead sea turtles captured alive $(n=24)$ and incidentally captured in depth-drifting longlines $(n=12)$ at the waters surrounding the Madeira Archipelago

\begin{tabular}{|c|c|c|c|c|c|c|}
\hline \multirow[t]{2}{*}{ Biometrical parameter } & \multicolumn{3}{|c|}{ Live turtles } & \multicolumn{3}{|c|}{ Turtle bycatch } \\
\hline & $n$ & Median \pm SD & Range & $n$ & Median \pm SD & Range \\
\hline Straight carapace length & 23 & $332 \pm 111$ & $195-571$ & 12 & $381 \pm 62$ & $264-493$ \\
\hline Minimum straight carapace length & 23 & $327 \pm 109$ & $193-561$ & 12 & $375 \pm 60$ & $262-486$ \\
\hline Straight carapace width & 24 & $285 \pm 94$ & $170-500$ & 12 & $332 \pm 53$ & $234-434$ \\
\hline Curved carapace length & 23 & $374 \pm 122$ & $228-632$ & 12 & $421 \pm 63$ & $299-532$ \\
\hline Minimum carapace curved length & 23 & $364 \pm 120$ & $223-619$ & 12 & $412 \pm 63$ & $291-524$ \\
\hline Curved carapace width & 24 & $345 \pm 119$ & $207-604$ & 12 & $402 \pm 65$ & $275-519$ \\
\hline Post-cloacal tail length & 24 & $14 \pm 6$ & $6-27$ & 12 & $17 \pm 4$ & $10-24$ \\
\hline Head length & 24 & $96 \pm 26^{\mathrm{a}}$ & $58-151$ & 12 & $114 \pm 15^{\mathrm{a}}$ & $82-142$ \\
\hline Head width & 24 & $77 \pm 25$ & $46-143$ & 12 & $89 \pm 13$ & $64-114$ \\
\hline Right fore-flipper length & 24 & $191 \pm 60$ & $117-350$ & 12 & $220 \pm 31$ & $160-274$ \\
\hline Right fore-flipper width & 24 & $64 \pm 17$ & $42-99$ & 12 & $73 \pm 10$ & $55-89$ \\
\hline Fore-flipper first claw length & 24 & $11 \pm 3$ & $7-18$ & 12 & $13 \pm 2$ & $9-16$ \\
\hline Weight & 24 & $7740 \pm 7858$ & $1224-28,850$ & 12 & $9350 \pm 4499$ & $3078-18,800$ \\
\hline
\end{tabular}

The values are presented as mean \pm standard deviation, in millimetre $(\mathrm{mm})$. Weight is presented in gram $(\mathrm{g})$ ${ }^{a}$ Significant differences between groups: live and turtle bycatch $(P<0.05)$ 


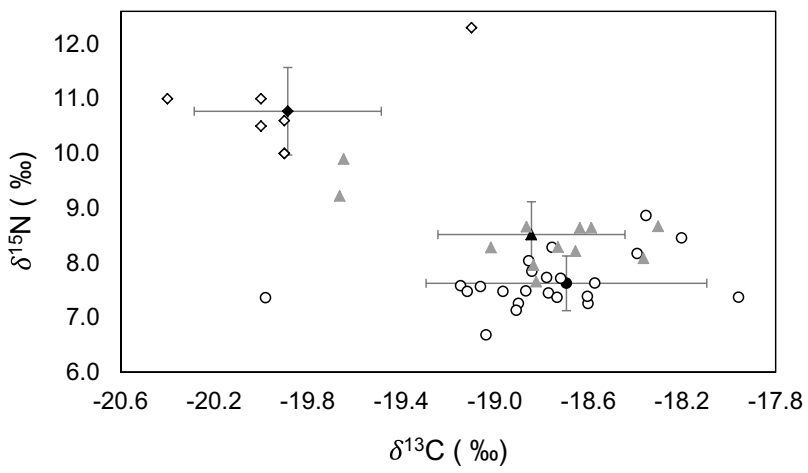

Fig. 3 Isotopic signatures of nitrogen $\left(\delta^{15} \mathrm{~N}\right)$ and carbon $\left(\delta^{13} \mathrm{C}\right)$ of loggerhead turtles Caretta caretta (mean \pm SD \%o) based on blood samples collected from free-ranging individuals (open circles, $n=24$ ), and individuals incidentally captured and killed in depthdrifting longlines (grey triangles, $n=12$ ), in the waters surrounding the Madeira Archipelago, Portugal. Open diamonds show isotopic signature from muscle tissue of neon flying squids Ommastrephes bartramii, used as baits in the longlines $(n=7)$

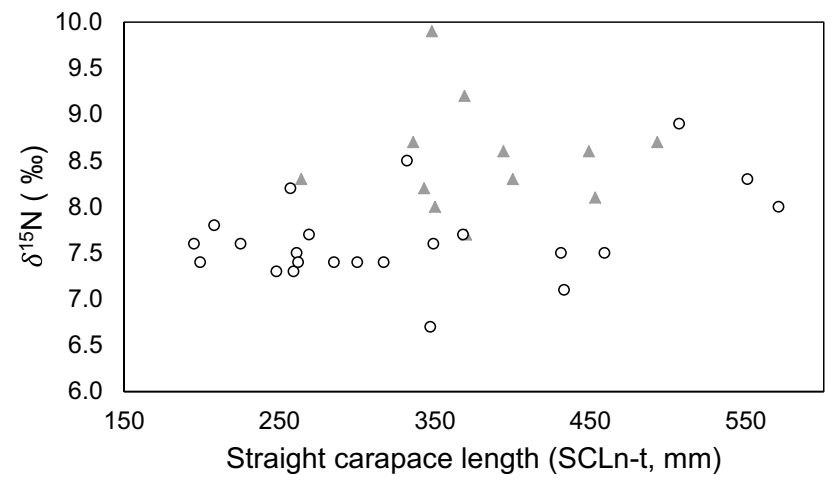

Fig. 4 Isotopic signatures of nitrogen $\left(\delta^{15} \mathrm{~N}\right)$ vs. body size (SCLnt) of loggerhead turtles Caretta caretta, based on blood samples collected from free-ranging individuals (open circles, $n=24$ ) and individuals incidentally captured and killed in the depth-drifting longlines (grey triangles, $n=12$ ), in the waters surrounding the Madeira Archipelago, Portugal. There was no effect of body size on $\delta^{15} \mathrm{~N}$ values

(one-way ANOVA, $F(1,29)=24.5, P<0.001$, Fig. 3 ) and turtle bycatch (one-way ANOVA, $F(1,17)=27.8, P<0.001$, Fig. 3).

\section{Discussion}

We characterized the trophic position of juvenile loggerhead sea turtles in the oceanic region of the Madeira Archipelago. Our stable isotope analysis revealed that the group of turtles incidentally caught and killed in the local depth-drifting longlines occupied a slightly higher trophic level than the group of turtles captured alive, within the same region. This suggests that either the turtle bycatch represent a different subgroup that consumed different prey types, with a higher trophic positions than those consumed by live turtles, or that they eat the same type of prey, but their relative prevalence is sufficiently different to create a distinct $\delta^{15} \mathrm{~N}$ signal. We also verified that this discrepancy was not related to the body size, rejecting the hypothesis that larger animals were consuming larger preys and, therefore, feeding at a higher trophic level. Notably, there were no differences in the values of $\delta^{13} \mathrm{C}$ between the two groups of turtles. Since $\delta^{13} \mathrm{C}$ values in marine ecosystems allow to infer the foraging habitat (Hall et al. 2015), similar values of $\delta^{13} \mathrm{C}$ indicate that both groups likely forage on the same water mass and possibly in the same geographic areas hence with the same range of prey types available.

Although for the purpose of this study the turtles analysed are divided into two groups (turtles captured alive and turtle bycatch), there is no reason to believe they have different geographic origins. The turtles analysed most likely originate from western Atlantic nesting populations, as individuals from these populations are known to forage in the deep oceanic waters around Madeira (Bolten et al. 1998; Dellinger 2008; Mansfield et al. 2014). While we actively searched for live turtles relatively close to the shoreline $(<10 \mathrm{~nm})$, the fishing fleet operates far from the coast at distances of up to several hundred nautical miles. Therefore, the differences in the capture sites between the two groups were related to the different sampling locations as the turtles captured near shore and the turtles caught by fisheries offshore have overlapping in-water ranges. Previous work through the analysis of satellite tracking data on individual loggerheads caught alive over deep waters near Madeira (in virtually the same locations as in our live turtles group) indicate that turtles have an extremely short residency time in this particular area (see McCarthy et al. 2010), and hence are not associated with neritic habitats around Madeira, but rather use the broad deep-sea marine habitat of the broader region where turtles were caught by fisheries (the turtle bycatch).

A key aspect in ecological studies that involve the analysis of stable isotopes is the isotopic turnover, i.e. the time that it takes for a consumer's tissue to reflect the isotopic composition of its diet tissue (Hall et al. 2015). In ectothermic animals such as sea turtles, blood is a tissue that reflects recently consumed food resources, due to its high metabolic rates which lead to a turnover rate of $27.7 \pm 3.5$ days (Reich et al. 2008). This means that the whole blood of juvenile loggerheads roughly reflects the diet composition of turtles in the past month. The analysis of a tissue with a rapid turnover rate increases the probability that the isotopic values obtained represent the dietary composition of specimens in the study area. This is particularly important to take into account when dealing with highly migratory species. The mean residence time of juvenile loggerheads in the EEZ of 
the Madeira Archipelago was estimated by satellite telemetry at $51 \pm 33$ days (Dellinger and Freitas 2000). Considering this residence time and the rapid turnover rate of blood, the isotopic signatures presented here should correspond to the period when juvenile loggerheads inhabit the oceanic region of Madeira.

We postulate that the group of turtles incidentally captured in the depth-drifting longlines in the oceanic region of the Madeira Archipelago represents a segment of the population that exhibits a different foraging behaviour strategy. Such differential foraging behaviour is not necessarily resulting from an association with human fisheries. For example, some turtles may have a tendency to dive deeper, or consume more carrion, which would make them potentially more likely to be caught in longlines. Alternatively, this group of turtles may forage more on fishery-related food sources, such as bait and discards. However, the isotopic signatures of bait and of dead turtles do not suggest that the turtles that were caught had been regularly consuming significant quantities of bait. Among the adults of the loggerhead North Atlantic population, trophic specialization has been demonstrated, suggesting that specializations within generalist populations may be more common than previously thought (Vander et al. 2010). Furthermore, associations between fisheries and loggerhead sea turtles have previously been reported in neritic environments, with a long-term temporal shift in the diet of loggerheads coinciding with the target and discard species of the fishing industry in Chesapeake Bay, USA (Seney and Musick 2007). Wallace et al. (2009) also suggested a potential for competition between loggerheads and crab fisheries in North Carolina. It remains to be conclusively shown whether loggerhead turtles can also associate with fisheries in offshore pelagic environments. If indeed some individuals become accustomed to the food source from the fishery discards, or for other reasons are more prone to interact with fishing fleets, they will have a higher risk of mortality, so this has important conservation implications.

The information on the trophic level presented in this study is the first of its kind for the juveniles of $C$. caretta in the oceanic region of Madeira, and so provides an important contribution to the knowledge of the life history of this species. The suggested hypothesis of different foraging behaviour strategy, which will attract a portion of individuals from the population and increase the likelihood of death in depth-drifting longlines, has implications for the ecology of the species. An intra-population variation in the choice of diet may have evolutionary consequences, as heterogeneity of food resources presupposes a reduction in intraspecific competition that may alter selective pressures (Vander et al. 2010). Such variation also has conservation consequences, given that the group of juveniles that adopt the feeding strategy associated with the fisheries is less likely to survive. To confirm the hypothesis of a different foraging behaviour strategy it would be useful to carry out further studies with a larger number of individuals and to include both dead turtles in the 'live turtles' sample and live turtles in the 'turtle bycatch' sample. Additionally, the fact that turtle bycatch seems to have a different foraging niche to the turtles captured alive suggests that comprehensive studies of the foraging ecology and diet of sea turtles should not rely exclusively on turtles caught in longlines. It would also be useful to perform a detailed extensive analysis of the diet (i.e. a quantification of diet items in the digestive tract of turtles caught in the fisheries), associated with movement and dive patterns (monitored through satellite telemetry). To reduce the mortality in the fishing gears, it would be beneficial to adopt guidelines that promote a sustainable exploitation of marine resources. Specifically, it could be effective to change the type of bait and the type of hook used in the depth-drifting longlines. The replacement of squids, which have a positive buoyancy, by mackerels, which sink in salt water, and replacement of J-style hooks by circle hooks, are two effective measures shown to reduce incidental sea turtle catch rates without significant loss of fishing profitability (Coelho et al. 2015). Additionally, knowledge on the foraging habitat preferences of juvenile loggerheads could be applied to designate a spatial distribution of fishing operations that minimized interactions (McCarthy et al. 2010).

Here we present the first assessment of the trophic position occupied by the oceanic juvenile loggerhead sea turtles foraging in the waters around the Madeira Archipelago. We suggest that during this life stage some individuals develop a foraging behaviour that enhances their risk of interaction with fisheries, leading to a higher risk of mortality, and underline the urge for further foraging ecology research and the application of bycatch reduction measures and other sea turtle-fishery interactions.

Acknowledgements We thank the efforts of all people involved in the fieldwork and in the laboratory work, and the collaboration of the local fishers. This study was conducted under the license of Madeira's Natural Park and the research was funded by the Portuguese Foundation for Science and Technology (FCT) through the project OceanWebs: Trophic links in open oceans: combining spatial data, dietary and functioning of subtropical pelagic ecosystems (PTDC/MARPRO/0929/2014), the strategic projects UID/MAR/04292/2013, IF/00502/2013/CP1186/CT0003 and UID/AMB/50017/2013 granted to MARE and CESAM, respectively, and European Regional Development Fund, within the PT2020 Partnership Agreement and Compete 2020.

Funding This study was funded by the Portuguese Foundation for Science and Technology through the project OceanWebs: Trophic links in open oceans: combining spatial data, dietary and functioning of subtropical pelagic ecosystems (PTDC/MAR-PRO/0929/2014), and the strategic projects UID/MAR/04292/2013, IF/00502/2013/CP1186/ CT0003 and UID/AMB/50017/2013 granted to MARE and CESAM, respectively, and the European Regional Development Fund; PT2020 Partnership Agreement and Compete 2020. 


\section{Compliance with ethical standards}

Conflict of interest Author CR declares that she has no conflict of interest. Author ARP declares that she has no conflict of interest. Author PC declares that he has no conflict of interest. Author TD declares that he has no conflict of interest. Author JPG declares that he has no conflict of interest.

Ethical approval All procedures were approved by the Animal Welfare Body of the Faculty of Sciences, University of Lisbon (Statement 2/2016) and license 0421/000/000/2016 issued by the competent governmental agency (Direção Geral da Alimentação e Veterinária), and followed recommended guidelines (Bolten 1999, NOAA 2008). No animal experiments were conducted for the purpose of this study.

\section{References}

Avens L, Snover ML (2013) Age and age estimation in sea turtles. In: Wyneken J, Lohmann KJ, Musick JA (eds) The biology of sea turtles, vol III. RC Press, Boca Raton, pp 97-134

Bjorndal KA, Bolten AB, Martins HR (2000) Somatic growth model of juvenile loggerhead sea turtles Caretta caretta: duration of pelagic stage. Mar Ecol Prog Ser 202:265-272. https://doi.org/10.3354/ meps 202265

Bjorndal KA, Bolten AB, Dellinger T, Delgado C, Martins HR (2003) Compensatory growth in oceanic loggerhead sea turtles: response to a stochastic environment. Ecology 84:1237-1249. https://doi. org/10.1890/0012-9658(2003)084\%5b1237:cgiols\%5d2.0.co;2

Bolten AB (1999) Techniques for measuring sea turtles. In: Eckert KL, Bjorndal KA, Abreu-Grobois FA, Donnelly M (eds) Research and management techniques for the conservation of sea turtles. IUCN/SSC Marine Turtle Specialist Group Publication No. 4, pp 110-114

Bolten AB, Bjorndal KA, Martins HR, Dellinger T, Biscoito MJ, Encalada SE, Bowen BW (1998) Transatlantic developmental migrations of loggerhead sea turtles demonstrated by mtDNA sequence analysis. Ecol Appl 8:1-7. https://doi.org/10.1890/10510761(1998)008\%5b0001:tdmols\%5d2.0.co;2

Ceriani SA, Roth JD, Evans DR, Weishampel JF, Ehrhart LM (2012) Inferring foraging areas of nesting loggerhead turtles using satellite telemetry and stable isotopes. PLoS One 7:e45335. https://doi. org/10.1371/journal.pone.0045335

Coelho R, Santos MN, Fernandez-Carvalho J, Amorim S (2015) Effects of hook and bait in a tropical northeast Atlantic pelagic longline fishery: part I-incidental sea turtle bycatch. Fish Res 164:302-311. https://doi.org/10.1016/j.fishres.2014.11.008

Dellinger T (2008) Tartarugas marinhas. In: Loureiro A, Ferrand de Almeida N, Carretero MA, Paulo OS (eds) Atlas dos Anfíbios e Répteis de Portugal. Instituto da Conservação da Natureza e Biodiversidade, Lisboa, pp 193-209

Dellinger T, Freitas C (2000) Movements and diving behaviour of pelagic stage loggerhead sea turtles in the North Atlantic: preliminary results obtained through satellite telemetry. In: Kalb H, Wibbels T (eds) Proceedings of the nineteenth annual symposium on sea turtle biology and conservation. NOAA Technical Memorandum NMFS-SEFSC-443, South Padre Island, Texas, USA, pp 155-157

Development Core Team (2008) R: a language and environment for statistical computing. R Foundation of Statistical Computing, Vienna

Encarnação HPO (1998) Captura acidental de tartarugas marinhas pela frota de pesca madeirense. Relatório de Estágio do Curso de Biologia, Universidade da Madeira, Funchal
Freitas C, Caldeira R, Reis J, Dellinger T (2018) Foraging behavior of juvenile loggerhead sea turtles in the open ocean: from Lévy exploration to area-restricted search. Mar Ecol Prog Ser 595:203215. https://doi.org/10.3354/meps 12581

Frick MG, Williams KL, Bolten AB, Bjorndal KA, Martins HR (2009) Foraging ecology of oceanic-stage loggerhead turtles Caretta caretta. Endanger Species Res 9:91-97. https://doi.org/10.3354/ esr00227

Hall AG, Avens L, Mcneill JB, Wallace B, Goshe LR (2015) Inferring long-term foraging trends of individual juvenile loggerhead sea turtles using stable isotopes. Mar Ecol Prog Ser 537:265-276. https://doi.org/10.3354/meps11452

Hatase H, Takai N, Matsuzawa Y, Sakamoto W, Omuta K, Goto K, Arai N, Fujiwara T (2002) Size-related differences in feeding habitat use of adult female loggerhead turtles Caretta caretta around Japan determined by stable isotope analyses and satellite telemetry. Mar Ecol Prog Ser 233:273-281. https://doi.org/10.3354/ meps 233273

Jones TT, Seminoff JA (2013) Feeding biology: advances from fieldbased observations, physiological studies, and molecular techniques. In: Wyneken J, Lohmann KJ, Musick JA (eds) The biology of sea turtles, vol III. CRC Press, Boca Raton, pp 211-248

Lucchetti A, Sala A (2010) An overview of loggerhead sea turtle (Caretta caretta) bycatch and technical mitigation measures in the Mediterranean Sea. Rev Fish Biol Fish 20:141-161. https:// doi.org/10.1007/s11160-009-9126-1

Mansfield KL, Wyneken J, Porter WP, Luo J (2014) First satellite tracks of neonate sea turtles redefine the "lost years" oceanic niche. Proc R Soc B Biol Sci 281:20133039. https://doi.org/10.1098/ rspb.2013.3039

McCarthy AL, Heppell S, Royer F, Freitas C, Dellinger T (2010) Identification of likely foraging habitat of pelagic loggerhead sea turtles (Caretta caretta) in the North Atlantic through analysis of telemetry track sinuosity. Prog Oceanogr 86:224-231. https://doi. org/10.1016/j.pocean.2010.04.009

McClellan CM, Read AJ (2007) Complexity and variation in loggerhead sea turtle life history. Biol Lett 3:592-594. https://doi. org/10.1098/rsbl.2007.0355

Moreira CSP (2006) Alimentação das tartarugas marinhas comuns (Caretta caretta) em águas da Madeira através de análise dos conteúdos estomacais. Relatório de Estágio da Licenciatura em Biologia Marinha e Biotecnologia, Instituto Politécnico de Leiria, Escola Superior de Tecnologia do Mar, Peniche

Parker DM, Cooke WJ, Balazs GH (2003) Diet of oceanic loggerhead sea turtles (Caretta caretta) in the central North Pacific. Fish Bull 103:142-152

Reich KJ, Bjorndal KA, del Rio CM (2008) Effects of growth and tissue type on the kinetics of ${ }^{13} \mathrm{C}$ and ${ }^{15} \mathrm{~N}$ incorporation in a rapidly growing ectotherm. Oecologia 155:651-663. https://doi. org/10.1007/s00442-007-0949-y

Seminoff JA, Jones TT, Eguchi T, Jones DR, Dutton PH (2006) Stable isotope discrimination ( $\delta 13 \mathrm{C}$ and $\delta 15 \mathrm{~N}$ ) between soft tissues of the green sea turtle Chelonia mydas and its diet. Mar Ecol Prog Ser 308:271-278. https://doi.org/10.3354/meps308271

Seney EE, Musick JA (2007) Historical diet analysis of loggerhead sea turtles (Caretta Caretta) in Virginia. Copeia 2007:478-489. https ://doi.org/10.1643/0045-8511(2007)7\%5b478:hdaols\%5d2.0.co;2

van Nierop MM, den Hartog JC (1984) A study on the gut contents of five juvenile loggerhead turtles, Caretta caretta (Linnaeus) (Reptilia, Cheloniidae), from the south-eastern part of the North Atlantic Ocean, with emphasis on Coelenterate identification. Zool Meded 59:35-54

Vander Zanden HB, Bjorndal KA, Reich KJ, Bolten AB (2010) Individual specialists in a generalist population: results from a long-term stable isotope series. Biol Lett 6:711-714. https://doi. org/10.1098/rsbl.2010.0124 
Wallace BP, Avens L, Braun-McNeill J, McClellan CM (2009) The diet composition of immature loggerheads: Insights on trophic niche, growth rates, and fisheries interactions. J Exp Mar Biol Ecol 373:50-57. https://doi.org/10.1016/j.jembe.2009.03.006

Wolke RE, George A (1981) Sea turtle necropsy manual. In: NOAA Tech Memo NMFS-SEFC, pp 1-24
Publisher's Note Springer Nature remains neutral with regard to jurisdictional claims in published maps and institutional affiliations. 